\title{
Cultural Consonance, Religion and Psychological Distress in an Urban Community ${ }^{1}$
}

\author{
William W. Dressler ${ }^{2}$ \\ H. J. Francois Dengah II \\ University of Alabama, Tuscaloosa-AL, United States of America \\ Mauro Campos Balieiro \\ Universidade Paulista, Ribeirão Preto-SP, Brazil \\ José Ernesto dos Santos \\ Universidade de São Paulo, Ribeirão Preto-SP, Brazil
}

\begin{abstract}
Cultural consonance is the degree to which individuals approximate prototypes encoded in cultural models. Low cultural consonance is associated with higher psychological distress. Religion may moderate the association between cultural consonance and psychological distress. Brazil, with substantial variation in religion, is an important society for the examination of this hypothesis. Research was conducted in Ribeirão Preto, Brazil, using a mixed-methods design. Measures of cultural consonance were derived using ethnographic methods and then applied in a survey of 271 individuals drawn from four distinct social strata. Low cultural consonance was associated with higher psychological distress in multiple regression analysis $(B=-.430, p<.001)$. Members of Pentecostal Protestant churches reported lower psychological distress independently of the effect of cultural consonance $(B=-.409$, $p<.05)$. There was no buffering effect of religion. Implications of these results for the study of religion and health are discussed.
\end{abstract}

Keywords: culture, religion, psychological stress

\section{Consonância Cultural, Religião e Sofrimento Psicológico em uma Comunidade Urbana}

\begin{abstract}
Resumo: Consonância cultural é o grau em que os indivíduos se aproximam dos protótipos codificados nos modelos culturais. Consonância cultural baixa é associada a sofrimento psicológico. A religião pode moderar a associação entre consonância cultural e sofrimento psicológico. O Brasil apresenta uma diversidade religiosa, sendo, portanto, uma sociedade importante para examinar esta hipótese. Este estudo, realizado em Ribeirão Preto, Brasil, utilizou delineamento de métodos mistos. As medidas de consonância cultural foram derivadas de métodos etnográficos e aplicadas em um estudo de levantamento realizado com 271 participantes, selecionados de quatro estratos socias. Consonância cultural baixa mostrou-se associada a sofrimento psicológico alto em análise de regressão múltipla $(B=-0,430, p<0,001)$. Membros de igrejas protestantes pentecostais relataram menor sofrimento psicológico independente dos efeitos da consonância cultural $(B=-0,409, p<0,05)$. A religião não moderou o efeito da consonância. São discutidas as implicações desses resultados para o estudo da relação entre religião e saúde.
\end{abstract}

Palavras-chave: cultura, religião, stress psicológico

\section{La Consonancia Cultural, la Religión, y los Trastornos Psicológicos en una Comunidad Urbana}

\begin{abstract}
Resumen: Consonancia cultural es el grado en que individuos se acercan a prototipos codificados en modelos culturales. Consonancia cultural baja está asociada con alto nivel de trastornos psicológicos. La religión puede moderar la relación entre consonancia cultural y trastornos psicológicos. Brasil, con variación religiosa considerable, es una sociedad importante para examinar esta hipótesis. La investigación fue realizada en Ribeirão Preto, Brasil, utilizando un diseño de métodos mixtos. Medidas de consonancia cultural se obtuvieron utilizando métodos etnográficos y luego se aplican en una encuesta de 271 personas procedentes de cuatro estratos sociales. Consonancia cultural baja se asoció con una mayor angustia psicológica en el análisis de regresión múltiple $(B=-.430$, $p<.001)$. Los miembros de las iglesias protestantes pentecostales manifiestan una menor angustia psicológica independientemente del efecto de la consonancia cultural $(B=-.409, p<.05)$. La religión no moderó el efecto de la consonancia. Las implicaciones de estos resultados para el estudio de la relación entre religión y salud se discuten.
\end{abstract}

Palabras clave: cultura, religión, estrés psicológico

The hypothesis that religion influences health, including psychological distress, is an old one in the social sciences

\footnotetext{
1 Support: National Science Foundation from the United States of America (BCS-0091903)

2 Correspondence address:

William W. Dressler. Department of Anthropology. University of Alabama, Tuscaloosa-AL, United States of America. 35487-0210.

E-mail: wdressle@as.ua.edu
}

(Ellison \& Levin, 1998). Religion can provide individuals with the social, psychological, and spiritual resources for coping with the inevitable stresses of everyday life (Chesnut, 1997). This hypothesis can be effectively examined in Brazil because of the variation in formal religion found there (Greenfield, 2008). Throughout its history there has been religious diversity in Brazil. More recently, however, that diversity has increased dramatically, due to the growth of Pentecostal Protestant 
religions, the members of which are popularly referred to as evangélicos in Brazil (Stoll, 1990). Substantial numbers of Brazilians are converting to Pentecostal Protestantism, while at the same time, Brazil remains the world's largest Catholic country. Add to this the importance of spiritism which, while not a codified religion per se, serves a similar function in peoples' lives, and Brazil offers an interesting test case for the study of religion and psychological distress.

Religion cannot, however, be looked at in isolation, since there are a variety of factors in the social environment that influence psychological distress. We have investigated cultural influences on psychological distress for over twenty years in an urban center in Brazil. Specifically, we have examined the influence of "cultural consonance," which is the degree to which individuals, in their own beliefs and behaviors, approximate the prototypes for belief and behavior encoded in shared cultural models (Dressler, 2007). When examined in the context of cultural domains that define major life goals, cultural consonance can be thought of as a measure of "success" in your society, because you are seen by others as achieving those goals that are collectively defined as important. And, the higher one's cultural consonance, the lower the psychological distress (Dressler, 2007, 2012; Dressler, Balieiro, \& Santos, 2002; Dressler, Balieiro, Ribeiro \& Santos, 2007a, 2007b). In all of these studies, cultural consonance is associated with psychological distress independently of socioeconomic status and other measures of life stress, and other measures of life stress do not mediate the effects of cultural consonance (Balieiro, Santos, Santos, \& Dressler, 2011).

In general, Pentecostal religions in Brazil have seen most of their converts come from lower social classes (although this is a tendency, not a hard rule). Chesnut (1997), in his ethnographic study of Pentecostal Protestantism in Brazil, specifically suggests that these religions have taken hold because they provide individuals with a way to cope with their social, economic, and cultural marginality. These ideas converge with our work on cultural consonance and suggest a specific hypothesis: does membership in a Pentecostal Protestant religion moderate or buffer the impact of low cultural consonance on psychological distress?

\section{Cultural Consonance}

The concept of cultural consonance fills a void in anthropological theory by explicitly connecting culture as a descriptor of aggregates (e.g., social groups) to individuals within those groups. Culture is conceptualized as the shared knowledge and understanding individuals must possess to function adequately within the group (Goodenough, 1996). This shared knowledge or understanding is encoded in cultural models or schema. These are cognitive structures that describe a given cultural domain. A cultural domain is any organized sphere of discourse within a society. It is anything around which talk is structured (e.g., the family, football). The cultural model for a domain consists of the elements making up the domain, along with prototypical processes that organize the relationships among those elements (D'Andrade, 1995). So, for example, in the cultural model of family life that we have examined, elements of the model include characteristics of the family that describe a good family (e.g., love, comprehension, unity, structure, and organization), and processes that link those elements (e.g., family organization and affect are mutually reinforcing) (Dressler, 2005).

Cultural models can be investigated using a variety of methods, including traditional ethnographic interviewing and the more systematic methods of cultural domain analysis (Borgatti, 1999). These latter methods include: free list interviews, which are techniques for eliciting the elements within a domain; unconstrained pile sorts, which are interview techniques for exploring how a cultural domain is structured; and, cultural consensus analysis, which is a technique for verifying that the dimensions of meaning structuring a cultural domain are shared within a society (Weller, 2007; Romney, Weller, \& Batchelder, 1986).

Cultural domain analysis provides the investigator a systematic set of techniques for estimating the cultural knowledge and understanding that individuals share within a society. It does not, however, provide a measure of the degree to which individuals actually act on that knowledge and understanding in formulating their own individual beliefs and behaviors. The concept and measurement of cultural consonance provides this link. Drawing on the detailed description of cultural knowledge provided by cultural domain analyses, measures of belief and behavior within specific domains can be formulated for individuals, so that a direct measure of how closely they approximate the prototypical beliefs and behaviors described in a cultural model can be derived (Dressler, 2007, 2012).

The concept of cultural consonance was developed in research in Brazil (Lotufo, 2001). In a series of studies conducted in a Brazilian city, we have examined cultural consonance in several cultural domains that structure major life goals. These include lifestyles (material goods and leisure activities necessary for having a good life); social support (the network of individuals who provide help or assistance in times of felt need); family life (the characteristics of the family that make a good Brazilian family); and, national identity (the sense of belonging to the national community). Measures of cultural consonance have been developed for these specific cultural domains. Also, we have found that individuals who are culturally consonant in one domain tend to be consonant in other domains, resulting in a generalized cultural consonance. Higher cultural consonance is associated with lower psychological distress (Balieiro, et al., 2011; Dressler, et al., 2002; Dressler, et al., 2007a, 2007b); lower arterial blood pressure (Dressler \& Santos, 2000; Dressler, Balieiro \& Santos, 1998; Dressler, Balieiro, Ribeiro, \& Santos, 2005); and, lower body mass index (Santos, Oths, \& Dressler, 2001; Dressler, Oths, Ribeiro, Balieiro, \& Santos, 2008; Dressler, Oths, Balieiro, Ribeiro, \& Santos, 2012). These associations can be observed both for cultural consonance in specific cultural domains, and for generalized cultural consonance. The basic interpretation for these findings is that low cultural consonance is a chronically stressful experience. Persons with low cultural consonance see themselves, and are seen by others, not to have achieved success 
in culturally valued areas of life. In terms suggested by Antonovsky (1979), persons with low cultural consonance lack a "sense of coherence." They understand how life is supposed to be, as defined by shared cultural models. But they are unable to achieve that life themselves, as indicated by their low cultural consonance. This results in a sense of loss, frustration, and self-doubt, the outcome of which is chronic stress and a risk of psychological distress. The question, however, is: can religion buffer or protect individuals from this threat to their identity?

\section{Religion in Brazil}

The history of religion in Brazil is one of diversity, yet in the context of the overwhelming power of the Catholic Church. Beginning with the colonization of Brazil in the 16th century, the Catholic Church has been dominant, working at times in concert with, and at times in opposition to, political institutions. At the same time, the Catholic Church itself is not a monolithic whole, and its presence in Brazil more accurately reflects a non-Romanized, Iberian style of Catholicism (Mariz, 1994). Brazilian Catholicism includes various "folk Catholicisms" practiced in different parts of Brazil and, even within the church hierarchy, the weak Roman presence has lead to conflicting views between more traditional and more progressive elements of the priesthood. Most recently, there has been contention regarding the popular Charismatic Catholicism movement, which liberally borrows Pentecostal Christianity (Cleary, 2007; Steil, 2004). It is perhaps unsurprising that the most populous Catholic country in the world also has a vibrant religious marketplace awash with religious pluralism.

Even at the very beginning of Brazilian society, competing cultural models of the sacred within the population have been tolerated, if not endorsed (Brown \& Bick, 1987; Greenfield, 2008; Mariz, 1994). African slaves arrived with their own understanding of the supernatural, and they were converted by their masters to Catholicism, usually at the insistence of the resident priests. But unique characteristics of Brazilian slavery, such as the organization of enslaved populations into "nações" (literally "nations" of slaves from similar linguistic areas) and constant importation of slaves from Africa (rather than relying on a self-reproducing population), allowed the enslaved population to hold onto their own cultural models to a degree that was not seen in other slave-economies of the Western hemisphere (Mariz, 1994; Skidmore, 2010). What resulted was an incorporation of European beliefs with traditional African religions, ultimately forming and developing the various Afro-syncretic religions known today in Brazil, including candomblé, umbanda, and batuque (Brown, 1994).

European Protestant religions began to form in the early days of the development of Brazilian society but had relatively limited impact. Of greater impact was the development, three centuries after the Protestant Revolution, of spiritism in Europe, and especially the work of Allan Kardec. Kardec formulated what might be considered more of a philosophy than a religion, but it nevertheless competes in the religious marketplace today. The foundation of spiritist beliefs involve the progressive evolution of the spirit in this life and others, primarily through good works. Spiritism today claims a substantial number of adherents in Brazil, often in concert with, rather than in opposition to, other forms of belief (Greenfield, 2008).

As noted earlier, the major growth and expansion of religion in Brazil, starting in the early 20th century and accelerating since then, has been the growth of Pentecostal Protestantism. Pentecostal Protestantism started in Brazil with the 1910 arrival, via the United States, of two Swedish missionaries, Daniel Berg and Gunnar Vingren to Balém. A year later the duo, with 18 followers, would found the Missão de Fé Apostólica church, later renamed the Assembléia de Deus (Chesnut, 1997; Stoll, 1990). Since that humble beginning, Protestantism has expanded such that membership includes $22 \%$ of the population of Brazil, the majority $(60 \%)$ adhering to a Pentecostal style of the faith. The Igreja Assembléia de Deus is by far the most populous Protestant denomination, claiming over 12 million followers, followed distantly by Baptists with less than 4 million followers (Instituto Brasileiro de Geografia e Estatística [IBGE], 2012). A number of authors have noted (Chesnut, 1997; Mariz, 1994; Stoll, 1990) that these churches tend to draw the majority of their adherents from the lower socioeconomic statuses of Brazilian society. Due to their economic and social marginality, many poorer Brazilians are denied full participation in Brazilian society and culture. Chesnut (1997) and others (e.g., Burdick, 1998; Freston, 1995; Kramer, 2005; Mariz, 1994) argue that they turn to Pentecostal churches for several reasons, including the possibility endorsed by some churches that belief in God will ultimately provide material as well as spiritual benefits. Of course the desire for a stronger and more fulfilling spiritual life is a part of the motivation for some adherents. Chesnut (1997) argues, however, that a main motive for joining these churches is to be healed of afflictions of the body and the mind. Persons in lower social classes are at higher risk of physical and psychological disorders than those of higher social class standing (Antonovsky, 1979). Additionally, they are often without access to adequate medical care. Therefore, they may seek solace from their suffering in the spiritual life of the church and in the healing ceremonies that are a frequent part of worship services. In some Pentecostal churches, all illness and suffering are ascribed to demons that must be cast out for the person to recover and flourish (Oro, 2004). This form of healing may be especially important in helping to ameliorate the impact of a stressful low cultural consonance. Therefore, the objective of this paper is to examine the following hypothesis: membership in a Pentecostal church will moderate the association of cultural consonance and psychological distress; specifically, the regression coefficient for the association of cultural consonance and psychological distress will be smaller within Pentecostal church members than within other religious groups.

\section{Method}

Research on cultural consonance is carried out using a mixed-methods research design (Tashakkori \& Teddlie, 1998) 
and proceeds in two stages. The first stage is a cultural domain analysis (Borgatti, 1999) carried out to investigate the structure and sharing of cultural models of interest in a particular study. The second stage involves the development of measures of cultural consonance to assess how well individuals correspond in their beliefs and behaviors to those prototypical beliefs and behaviors encoded in shared cultural models. These measures are then employed in survey research to assess the association of cultural consonance and health outcomes (Dressler, 2007).

Research was carried out in Ribeirão Preto, Brazil, a city of 600,000 people in the north of the state of São Paulo. Ribeirão Preto is a center for agriculture, light manufacturing, education, and health care in this region of the state.

\section{Participants}

In the stage of cultural domain analysis, typically relatively small convenience samples can be used (Handwerker \& Wozniak, 1997). The emphasis in this stage of research is on learning about the particular categories and dimensions of meaning people use to structure a semantic domain. The result is an "emic" description of the domain, or one phrased in the terms that people themselves use in everyday conversation (D'Andrade, 1995). We employed interviews to free list terms associated with cultural domains of interest; interviews using unconstrained pile sorts to elicit dimensions of meaning that people use to differentiate terms within cultural domains; and, ratings and rankings along those dimensions to verify the salience of and sharing of those dimensions of meaning. Samples for each of these steps ranged from 40 to 66 persons, selected by convenience; however, in every step we selected individuals who differed by age, gender, and socioeconomic status (as indicated by educational level) in order to insure that we were sampling the diversity in Brazilian society (Dressler, Borges, Balieiro, \& Santos, 2005).

In the survey stage of the research, we used stratified random sampling; households were selected at random from complete enumerations of occupied households within each neighborhood. The sampling strata were four neighborhoods selected to represent socioeconomic status. The first was a lower class neighborhood that began as a squatter settlement. At one point the municipality razed the original neighborhood and moved the residents to a housing project of two-room, cinder-block houses. Residents could buy their houses with low-cost loans from the municipality. About half of the original residents remained in the new neighborhood, the other half replaced by people of slightly higher means who could purchase these houses. Residents tend to work as unskilled laborers and domestic servants. Despite the changes, the neighborhood retains an unsavory reputation for crime and drug trafficking.

The second neighborhood was a conjunto habitacional built in the late 1980s. Residents of this neighborhood tend to be of higher means and more stable employment that the lower class neighborhood. Also, over the years, this conjunto has grown considerably in terms of services, boasting supermarkets, pharmacies, clothing stores, small bars, and its own schools.
Residents tend to be employed in skilled working positions.

The third neighborhood was a traditional middle class area of the city. Adjacent to the city center, its residents are lower-level professionals and owners of small businesses. This area has its own large commercial center as well as a Catholic Church on its central plaza.

The fourth neighborhood was a gated community, home to upper-level professionals (doctors, lawyers, and university professors) and owners and managers of large businesses. These neighborhoods are described in more detail elsewhere (Dressler, Ribeiro, Balieiro, Oths, \& Santos, 2004; Dressler et al., 2007a).

Within each neighborhood, complete listings of occupied addresses were obtained and simple random samples of houses were selected using a computer-generated list of random numbers. Houses were visited by research assistants who invited the head of household, spouse of the household head, and one child over the age of 18 (if present) to participate in the research. The overall response rate was $71.2 \%$, for a final sample size of 271 . Non-participation occurred due to a lack of interest or time for participation on the part of respondents.

\section{Instruments}

As noted above, cultural domain analyses were carried out in the domains of lifestyle, social support, family life, and national identity. This measurement process is described in detail elsewhere (Dressler, Borges et al., 2005) and will be summarized here. In the initial stage of research cultural domain analysis was used to investigate these domains. In each domain we discovered a central dimension of importance. For example, in the domain of lifestyle, different kinds of material goods (e.g., a house, household furnishings, appliances) and different kinds of leisure time activities (going out with friends, having time to read and rest) were rated as more important than others (e.g., jewelry or fine clothing) for having a good life. In the domain of social support, some kinds of individuals (e.g., family and friends) were rated as more important sources of help in response to common problems (e.g., needing or borrow money, illness) than other kinds of persons (e.g., co-workers). In the domain of family life specific family characteristics (such as love, understanding, and organization versus lack of respect or egoism) were rated as more important for having a family. Similarly certain kinds of national characteristics (such as being friendly, loving carnaval) were rated as more important than others. In cultural consensus analysis, the sharing of the ratings of importance in each domain was confirmed (Dressler, Borges et al., 2005).

Then, using the results of the cultural consensus analysis, measures applicable to individuals were developed for use in survey research. In the domain of lifestyle, the culturally-valued items that people owned and the culturally-valued leisure activities in which they engaged were summed to provide a measure of cultural consonance in lifestyle. In the domain of social support, we asked individuals to rank order to whom they would turn for help in response to common problems, and then calculated a correlation between the individual rankings and the cultural consensus rankings. In the domains of family life and 
national identity, we developed Likert-response scales assessing the degree to which individuals perceived their own families as like the cultural consensus description of a good family, and the degree to which individuals perceived themselves and others to correspond to the culturally-salient characteristics of Brazilians. Each of scales exhibits acceptable psychometric characteristics (e.g., Cronbach's alpha >.70) and all four load a single principal component accounting for $46 \%$ of the total variance among the scales. A principal component score is used as a measure of generalized cultural consonance. These scales and their characteristics are described in detail elsewhere (Dressler et al., 2005). These scales have high emic validity, meaning that they rank order individuals along a continuum that is culturally meaningful within Brazilian society (Dressler \& Oths, 2012).

Individuals were asked to report their religion. The responses were grouped into four categories: Catholic; evangélico; spiritist; and, none/atheist. The majority of persons grouped as evangélico belong to a recognized Pentecostal denomination. There were a few individuals who reported membership in a conventional Protestant denomination (i.e., Baptist, Presbyterian, Methodist); these people were classified as evangélicos because there were too few to create a separate category.

Psychological distress was assessed by combining scales of depressive symptoms, perceived stress, and health locus of control. We used the Center for Epidemiologic Studies Depression Scale as translated and validated by Silveira \& Jorge (2000). Cohen's Perceived Stress Scale (Cohen, Karmack, \& Mermelstein, 1983), as translated and validated by Dressler and associates (Dressler, Balieiro, \& Santos, 1998, 2002) was also used. Finally, the Health Locus of Control scale of Coreil and Marshall (1982), as translated and validated by Dressler et al. $(1998,2002)$ was used. All of these scales have acceptable psychometric properties (Cronbach's alpha $>.80$ ), and all load a single principal component accounting for $65 \%$ of the total variance among the measures. This principal components score is used a summary measure of psychological distress (Dressler et al., 2007). Individuals with high scores on this scale report more depressive symptoms, more perceived stress, and have an external locus of control. Individuals with low scores on this scale report fewer depressive symptoms, less perceived stress, and an internal locus of control.

Age (in years), gender $(\operatorname{men}=1$; women $=0)$, and socioeconomic status are used as control variables. Socioeconomic status was assessed as a principal components score combining occupational prestige (Pastore, 1982), years of education completed, and family income (number of minimum salaries per month). A single principal component accounts for $61 \%$ of the total variance shared among these variables.

\section{Procedure}

Data analysis. All data included in this analysis were first analyzed using univariate descriptive statistics, including the mean, standard deviation, and percentages.

The hypothesis was tested using a hierarchical multiple regression analysis, with dummy variables representing the religious groups ("atheist/none" being the omitted category), and cultural consonance treated as a continuous variable (Cohen, Cohen, West, \& Aiken, 2003). In the analysis, the control variables (age, sex, and socioeconomic status) were entered as a block into the equation first. Then, cultural consonance was entered, along with the control variables. Next, the religious group dummy variables were entered as a block, along with the control variables and cultural consonance. In the dummy variable analysis, the magnitude of the regression coefficient can be interpreted as the mean difference between a category and the reference category. In this analysis, all continuous variables were first converted to $z$-scores, and dichotomies were in effects coding $(0,1)$. In this case, the unstandardized regression coefficients can be compared and are equivalent to standardized regression coefficients.

In a second analysis, a set of religion x cultural consonance interaction effects were introduced into the equation (see Cohen, et al., 2003 for a discussion of multiple regression analysis with dummy variables and interaction effects between continuous variables and dummy variables).

Potential multicollinearity was assessed by variable tolerance values and the variance inflation factor.

\section{Ethical Considerations}

The research protocol was reviewed and approved by the Institutional Review Board for the Protection of Human Subjects of the University of Alabama (02-039-1), and by the Research Ethics Committee of the Faculty of Medicine of Ribeirão Preto, the University of São Paulo-Ribeirão Preto (506/2002).

\section{Results}

Descriptive statistics for all variables included in the analysis are shown in Table 1 . With respect to religion, approximately $60 \%$ of respondents report their religion as Catholic and approximately $20 \%$ report themselves as evangélico. Another 10\% report being spiritist, and 10\% report either no religion or atheism.

Table 1

Descriptive Statistics

\begin{tabular}{lc}
\hline Variable & Descriptive Statistic \\
\hline Psychological distress & $0.00( \pm 1,0)$ \\
Age & $40.9( \pm 11.6)$ \\
Gender (\%) & \\
Males & 39.0 \\
Females & 61.0 \\
Socioeconomic status & $0.00( \pm 1.0)$ \\
Cultural consonance & $0.00( \pm 1.0)$ \\
Religion (\%) & \\
Catholic & 60.1 \\
Evangélico & 19.2 \\
Spiritist & 9.6 \\
None/atheist & 11.1 \\
\hline
\end{tabular}


As anticipated, persons reporting membership in a Pentecostal religion have lower levels of socioeconomic status and cultural consonance than any other religious group. Members of Pentecostal religions are 33\% below the mean for cultural consonance, and $66 \%$ below the mean for socioeconomic status $(p<.001)$.

Table 2 shows a hierarchical ordinary least squares regression analysis with psychological distress regressed on age, sex, socioeconomic status, cultural consonance, and religion. Higher cultural consonance is associated with lower psychological distress. Members of Pentecostal religions report significantly lower psychological distress than members of other religions. All tolerance values and the variance inflation factor for each variable were well within acceptable limits, indicating no significant multicollinearity. There were no significant interaction effects, so the results are not shown here.
The association of cultural consonance and psychological distress, separately by religion, is shown in Fig. 1.

\section{Discussion}

We began this paper with the suggestion that religion may moderate or buffer the impact of low cultural consonance on psychological distress in this urban community. This hypothesis has received partial support here. As we have shown elsewhere (Dressler et al., 2007a) and then confirmed here, low generalized cultural consonance is significantly associated with higher psychological distress. Low cultural consonance is a chronically stressful condition. Individuals with low cultural consonance have been unable to achieve major life goals that are valued in Brazilian society. They see themselves, and are seen by others, to

Table 2

Regression of Psychological Distress on Control Variables, Cultural Consonance, and Religion (Unstandardized Regression Coefficients Reported)

\begin{tabular}{lccc}
\hline Variables & Model 1 & Model 2 & Model 3 \\
\hline Age & -.064 & -.098 & -.107 \\
Gender & $-.348^{* *}$ & $-.350^{* *}$ & $-.365^{* * *}$ \\
Socioeconomic status & $-.188^{* *}$ & .033 & -.013 \\
Cultural consonance & - & $-.430^{* * *}$ & $-.427^{* * *}$ \\
Religion: & & & .022 \\
$\quad$ Catholic & - & - & $-.409^{*}$ \\
Evangélico & - & - & -.127 \\
Spiritist & - & .137 & .220 \\
Constant & .136 & $.459^{* * *}$ & $.486^{* * *}$ \\
Multiple R & $.275^{* * *}$ & & \\
\hline
\end{tabular}

${ }^{*} p<.05 ;{ }^{* *} p<.01 ;{ }^{* * *} p<.001$

lack this cultural consonance. This can lead to self-doubt, uncertain and unsatisfying social interactions, and a lack of a sense of coherence. The end result is greater psychological distress.

The hypothesis that religion moderates or buffers the chronic stress of low cultural consonance was not, however, supported. The stress buffering model has been specified analytically in two ways. The more common is through the testing of an interaction effect as we did here (Cleary \& Kessler, 1982). In this specification, a significant interaction would indicate that the impact of cultural consonance on psychological distress changes when a respondent reports that they belong to a Pentecostal church; but no such interaction was observed here. A second way of assessing a buffering effect, suggested by Pearlin and Schooler (1978), is to observe the change in the magnitude of the regression coefficient for the stressor variable of interest (in this case cultural consonance) when the potential moderating variable (religion) is introduced. If the magnitude of the effect of the stressor variable declines substantially, this is evidence of a moderating effect of the other variable. In this analysis, controlling for age, sex, and socioeconomic status, the effect of cultural consonance on psychological distress declines only slightly when the religion dummy variables are introduced (see Table 2).

At the same time, religion does influence psychological distress. When the religion dummy variables are introduced, their overall effect is significant, and that overall effect is generated by the effect of Pentecostal membership on psychological distress. It should also be kept in mind that members of Pentecostal religions have significantly lower socioeconomic status and cultural consonance, which would mean that they should be at higher risk of psychological distress. Yet, paradoxically, as shown in Table 2, they are at lower risk. Furthermore, the magnitude of the regression coefficient associated with membership in a Pentecostal church is nearly as great as that associated with a 
one standard deviation change in cultural consonance (although there is greater variability in psychological distress among evangélicos, hence the level of statistical significance is not as great).

Even though the interaction effects between cultural consonance and religion are not significant, it is interesting to plot the association of cultural consonance and psychological distress separately by religion, as shown in Fig. 1. Overall, clearly, as cultural consonance increases, psychological distress declines. Although the slope of this association does not differ significantly among religious groups (hence the interaction effects are non-significant), it is nevertheless interesting that, at least descriptively, that slope is smallest among members of Pentecostal religions.
In explaining the association of religion and health researchers have generally taken the stress-buffering model as paradigmatic. That is, buffers against life stress are usually thought to supply individuals under stress with resources they can use to either withstand the effects of stress or to actively mobilize efforts to cope with or alter stressors. These resources can take the form of social resources or social supports that provide help or assistance in times of felt need, or they can take the form of psychological resources in the form of information for dealing with stressors, or support for one's self-esteem and positive self-image (Ellison \& Levin, 1998). All of these may be at work here. That is, membership in a Pentecostal religion may indeed provide these kinds of

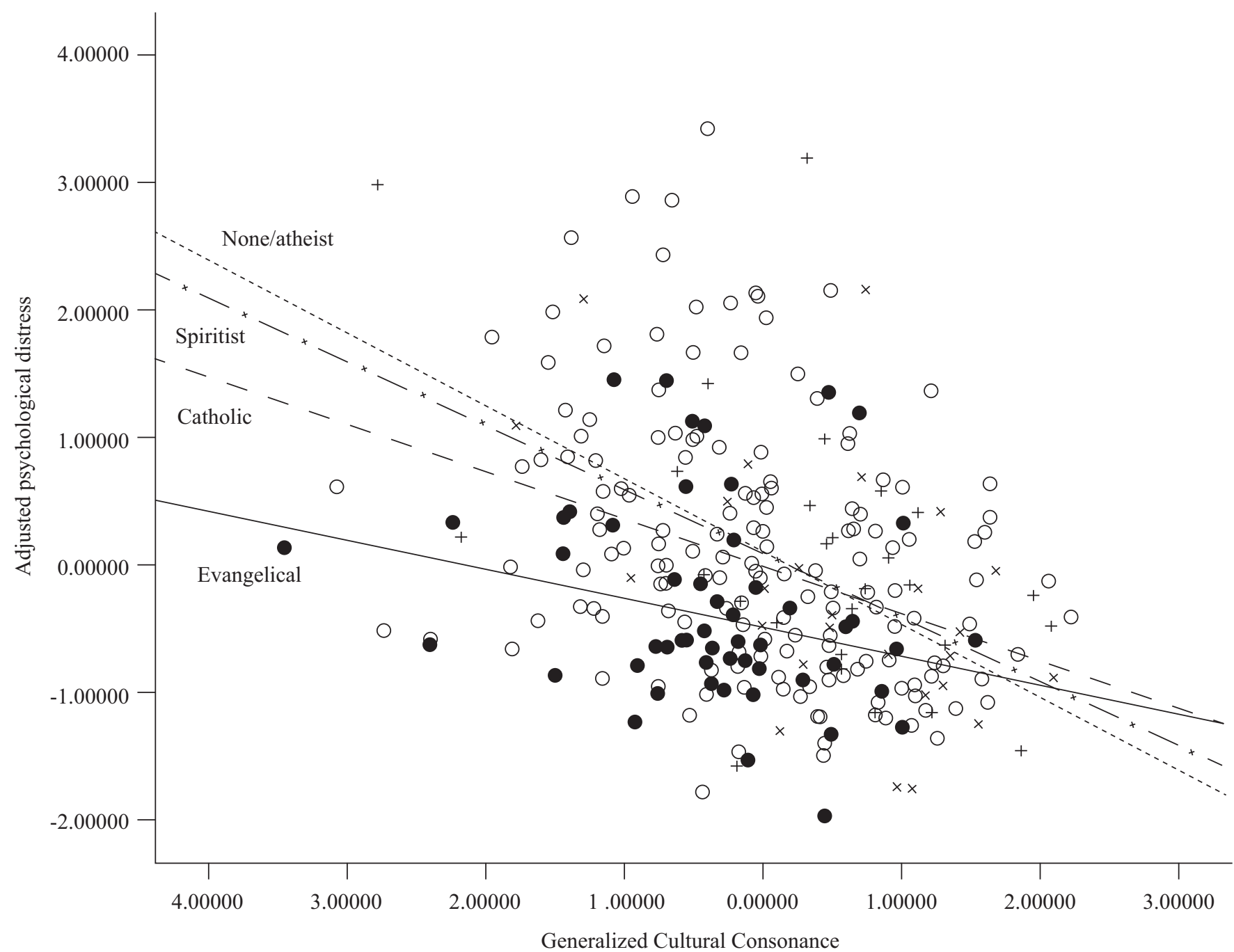

Figure 1. Association of cultural consonance and adjusted psychological distress by religion. Catholics $=$ small dotted line and open circles. Evangélicos $=$ solid line and + symbols. Spiritists $=$ dashed line and $\mathrm{x}$ symbols. None/atheist $=$ larger dotted line and closed circles

social and psychological resources. But, if that is the case, why would membership in other regions or religious-type groups (e.g., spiritists) not provide the same resources?

The results presented here suggest that there may be other processes at work, and the concept of cultural consonance may provide a clue to those processes. Cultural models provide individuals with a sense of meaning in life and a set of practical directions for living. The widely shared cultural models of lifestyle, social support, family life, and national identity all provide individuals with a sense of 
how to organize their lives materially and socially in terms of long-term goals. Furthermore, given that we observed a cultural consensus that extended across groups defined by age, gender, and socioeconomic status, these appear to be cultural models with a general distribution.

It certainly must be true, however, that there are other kinds of cultural models of a more limited distribution. For example, in the context presented here, there are certainly cultural models of a shared understanding of life associated with religious groups, especially with evangélicos and spiritists, that are of a more limited distribution. At the very least these models would define what it is to be a "good" or "authentic" evangélico or spiritista. Individuals who more closely match those models in their own beliefs and behaviors - who are, in other words, culturally consonant with these models of a more limited distribution - would in turn benefit psychologically from their success in achieving this consonance. While they might be less culturally consonant with the models of wider social distribution, they may benefit psychologically from their consonance with cultural models of a more narrow social distribution.

Therefore, it seems most likely that rather than offering a different set of shared life goals, the Pentecostal church supplements the more generally shared cultural models with a model or set of models that enable church members to achieve cultural consonance within that restricted social context and that this context-specific cultural consonance is in turn associated with lower psychological distress. Membership in a Pentecostal religion may not replace, nor moderate, the impact of cultural consonance; rather, it may offer an alternative pathway to the development of a positive sense of identity through higher cultural consonance within the religion. This second model does not supplant the general model, but rather supplements it. Perhaps their ability to achieve cultural consonance with this model of social support, that is shared within a more restricted social context, moderates the difficulties evangélicos have in achieving cultural consonance in other, more widely shared, domains.

These results suggest future directions in research on cultural consonance. If, as suggested, there are cultural models of more limited distribution guiding the understanding and behaviors of members of religious groups, these may in turn modify the effect of cultural consonance in more widely distributed models (like lifestyle and family life). In brief, cultural models should not be conceived of as individual units existing alongside each other, but as interconnected cognitive structures that may overlap, reinforce, contradict, or contend with each other. Socialization in new models can reorganize how previously held models are interpreted and valued (D'Andrade, 1995). The learning of certain religious models may alter how other models are used, valued, and enacted.

The results presented here are, of course, limited in that these associations have been examined in a limited context and within a specific sampling frame. Firm conclusions await replication.
Evidence indicates broad sharing in the cultural domains examined here. At the same time, these broadly shared cultural models may co-exist with other models that have a more restricted social distribution. Some individuals may not achieve cultural consonance in the broadly shared domains, but they may achieve consonance in more restricted domains, which in turn may positively contribute to adaptation.

\section{References}

Antonovsky, A. (1979). Health, stress and coping. San Francisco, CA: Jossey-Bass.

Balieiro, M. C., Santos, M. A., Santos, J. E., \& Dressler, W. W. (2011). Does perceived stress mediate the effect of cultural consonance on depression? Transcultural Psychiatry, 48(5), 519-538. doi: 10.1177/1363461511418873

Borgatti, S. P. (1999). Elicitation techniques for cultural domain analysis. In J. J. Schensul, M. D. LeCompte, B. K., Nastasi \& S. P. Borgatti (Eds.), Ethnographer's toolkit: Enhanced ethnographic methods, (Vol. 3, pp. 115-151). Walnut Creek, CA: Altamira Press.

Brown, D. D. (1994). Umbanda. New York: Columbia University Press.

Brown, D. D., \& Bick, M. (1987). Religion, class, and context: continuities and discontinuities in Brazilian Umbanda. American Ethnologist, 14(1), 73-93.

Burdick, J. (1998). Blessed Anastacia: Women, race and popular Christianity in Brazil. New York: Routledge.

Chesnut, R. A. (1997). Born again in Brazil: the Pentecostal boom and the pathogens of poverty. New Brunswick, N.J: Rutgers University Press.

Cleary, E. L. (2007). The Catholic Charismatic Renewal: Revitalization movements and conversion. In T. J. Steigenga \& E. L. Cleary (Eds), Conversion of a continent: Contemporary religious change in Latin America (pp. 153-173). New Brunswick, N.J.: Rutgers University Press.

Cleary, P. D., \& Kessler, R. C. (1982). The estimation and interpretation of modifier effects. Journal of Health and Social Behavior, 23(2), 159-169.

Cohen, J., Cohen, P., West, S. G., \& Aiken, L. S. (2003). Applied multiple regression/correlation analysis for the behavioral sciences. Mahwah, N.J.: L. Erlbaum Associates.

Cohen, S., Karmack, T., \& Mermelstein, R. (1983). A global measure of perceived stress. Journal of Health and Social Behavior, 24(4), 385-396.

Coreil, J., \& Marsall, P. (1982). Locus of illness control: A cross-cultural study. Human Organization, 41(2), 131-138.

D'Andrade, R. (1995). The development of cognitive anthropology. Cambridge: Cambridge University Press.

Dressler, W. W. (2005). What's cultural about biocultural research? Ethos, 33(1), 20-45. doi: 10.1525/eth.2005.33.1.020 
Dressler, W. W. (2007). Cultural consonance. In D. Bhugra $\&$ K. Bhui (Eds.), Textbook of Cultural Psychiatry (pp. 179-190). Cambridge: Cambridge University Press.

Dressler, W. W. (2012). Cultural consonance: Linking culture, the individual and health. Preventive Medicine, in press.

Dressler, W. W., \& Oths, K. S. (2012). Social survey research in anthropological fieldwork. In H.R. Bernard \& C.C. Gravlee (Eds.), Handbook of Research Methods in Anthropology, (2nd ed., in press). Walnut Creek, CA: Altamira

Dressler, W. W., \& Santos, J. E. (2000). Social and cultural dimensions of hypertension in Brazil: a review. Cadernos de Saúde Pública, 16(2), 303-315. doi: 10.1590/S0102-311X2000000200002

Dressler, W. W., Balieiro, M. C., \& Santos, J. E. (1998). Culture, socioeconomic status, and physical and mental health in Brazil. Medical Anthropology Quarterly, 12(4), 424-446. doi: 10.1525/maq.1998.12.4.424

Dressler, W. W., Balieiro, M. C., \& Santos, J. E. (2002). Cultural consonance and psychological distress. Paidéia: Cadernos de Psicologia e Educação, 12(22), 5-18.

Dressler, W. W., Balieiro, M. C., Ribeiro, R. P., \& Santos, J. E. (2005). Cultural consonance and arterial blood pressure in urban Brazil. Social Sience \& Medicine, 61(3), 527-540. doi: 10.1016/j.socscimed.2004.12.013

Dressler, W. W., Balieiro, M. C., Ribeiro, R. P., \& Santos, J. E. (2007a). Cultural consonance and psychological distress: Examining the associations in multiple cultural domains. Culture, Medicine \& Psychiatry, 31(2), 195-224. doi: 10.1007/s11013-007-9046-2

Dressler, W. W., Balleiro, M. C., Ribeiro, R. P., \& Santos, J. E. (2007b). A prospective study of cultural consonance and depressive symptoms in urban Brazil. Social Science \& Medicine, 65(10), 2058-2069. doi: 10.1016/j.socscimed.2007.06.020

Dressler, W. W., Borges, C. D., Balieiro, M. C., \& Santos, J. E. (2005). Measuring cultural consonance: examples with special reference to measurement theory in anthropology. Field Methods, 17(4), 331-355. doi: 10.1177/1525822X05279899

Dressler, W. W., Ribeiro, R. P., Balleiro, M. C., Oths, K. S., \& Santos, J. E. (2004). Eating, drinking and being depressed: the social, cultural and psychological context of alcohol consumption and nutrition in a Brazilian community. Social Science \& Medicine, 59(4), 709-720. doi: 10.1016/j.socscimed.2003.11.029

Dressler, W. W., Oths, K. S., Ribeiro, R. P., Balieiro, M. C., \& Santos, J. E. (2008). Cultural consonance and adult body composition in urban Brazil. American Journal of Human Biology, 20(1), 15-22. doi: 10.1002/ajhb.20674
Dressler, W. W., Oths, K. S., Balieiro, M. C., Ribeiro, R. P., \& Santos, J. E. (2012). How culture shapes the body: Cultural consonance and body mass in urban brazil. American Journal of Human Biology, 24(3), 325-331. doi: 10.1002/ajhb.22207

Ellison, C. G., \& Levin, J. S. (1998). The religion-health connection: Evidence, theory, and future directions. Health Education \& Behavior, 25(6), 700-720. doi: 10.1177/109019819802500603

Freston, P. (1995). Pentecostalism in Brazil: A brief history. Religion, 25(2),119-133. doi: 10.1006/reli.1995.0012

Goodenough, W. (1996). Culture. In David Levinson and Melvin Ember (Eds.), Encyclopedia of Cultural Anthropology (pp. 291-299). New York: Henry Holt.

Greenfield, S. M. (2008). Spirits with scalpels: The cultural biology of religious healing in Brazil. Left Coast Press.

Handwerker, W. P., \& Wozniak, D. E. (1997). Sampling strategies for the collection of cultural data. Current Anthropology, 38(5),869-875.

Instituto Brasileiro de Geografia e Estatística. (2012). Censo demográfico 2010: Características gerais da população, religião e pessoas com deficiência. Retrieved from http://www.ibge.gov.br/home/estatistica/populacao/ censo2010/caracteristicas_religiao_deficiencia/ default_caracteristicas_religiao_deficiencia.shtm.

Kramer, E. W. (2005). Spectacle and the staging of power in Brazilian Neo-Pentecostalism. Latin American Perspectives, 32(1), 95-120. doi: 10.1177/0094582X04271875

Lotufo, P. A. (2001). "The inverse equality hypothesis" and "cultural consonance": Two Brazilian contributions for a new public health agenda. São Paulo Medical Journal, 119(1), 2-3.

Mariz, C. L. (1994). Coping with poverty: Pentecostal and Christian base communities in Brazil. Philadelphia, PA: Temple University Press.

Oro, A. P. (2004). A presença religiosa brasileira no exterior: O caso da Igreja Universal do Reino de Deus. Estudos Avançados, 18(52), 139-155. doi: 10.1590/S0103-40142004000300011

Pastore, J. (1982). Inequality and social mobility in Brazil. Madison, WI: University of Wisconsin Press.Pearlin, L. I., \& Schooler, C. (1978). The structure of coping. Journal of Health and Social Behavior, 19(1), 2-21.

Romney, A. K., Weller, S. C., \& Batchelder, W. H. (1986). Culture as consensus: A theory of culture and informant accuracy. American Anthropologist, 88(2), 313-338. doi: 10.1525/aa.1986.88.2.02a00020

Santos, J. E., Oths, K. S., \& Dressler, W. W. (2001). Socioeconomic factors and adult body composition in a developing society. Revista Brasileira de Hipertensão, 8(2), 173-178. 
Silveira, D. X., \& Jorge, M. R. (2000). Escala de rastreamento populacional para depressão (CES-D) em populações clínica e não-clínica de adolescentes e adultos jovens. In C. Gorenstein, et al., (Eds.), Escalas de avaliação clínica em psiquiatria e psicofarmacologia (pp. 125-138). São Paulo, Brasil: Lemos-Editorial.

Skidmore, T. E. (2010). Brazil: Five centuries of change (2nd ed.). New York: Oxford University Press.

Steil, C. A. (2004). Renovação Carismática Católica: Porta de entrada ou de saída do catolicismo? Uma etnografia do Grupo São José, Porto Alegre. Religião e Sociedade, 24(1), 182-190.

Stoll, D. (1990). Is Latin America turning Protestant? The politics of evangelical growth. Berkeley: University of California Press.

Tashakkori, A., \& Teddlie, C. (1998). Mixed methodology: Combining qualitative and quantitative approaches. Thousand Oaks, CA: Sage Publications.

Weller, S. C. (2007). Cultural consensus theory: Applications and frequently asked questions. Field Methods, 19(4), 339-368. doi: 10.1177/1525822X07303502

William W. Dressler is a Professor of the Department of Anthropology at the University of Alabama.

H. J. Francois Dengah II is an Instructor at the University of Alabama.

Mauro Campos Balieiro is a Full Professor of the Universidade Paulista.

José Ernesto dos Santos is an Associate Professor at the Faculdade de Medicina de Ribeirão Preto of the Universidade de São Paulo.

Received: Aug. $17^{\text {th }} 2012$

$1^{\text {st }}$ Revision: Jul. $18^{\text {th }} 2013$

Approved: Sep. $19^{\text {th }} 2013$

How to cite this article:

Dressler, W. W., Dengah II, H. J. F., Balieiro, M. C., \& dos Santos, J. E. (2013). Cultural consonance, religion, and psychological distress in an urban community. Paidéia (Ribeirão Preto), 23(55), 151-160. doi:10.1590/1982-43272355201302 